\title{
Efektivitas Pelayanan Calon Pekerja Migran Indonesia Pada Layanan Terpadu Satu Atap Dinas Tenaga Kerja Dan Transmigrasi Kabupaten Subang
}

\author{
Reza Ronaldo ${ }^{1}$ \\ Sekolat Tinggi Ekonomi dan Bisnis Islam Lampung \\ rezaronaldo19967@gmail.com
}

Agus Dedi Subagja ${ }^{2}$

Fakultas Ilmu Administrasi Universitas Subang ads270577@gmail.com

\section{Ade Suparman ${ }^{3}$}

Fakultas Ilmu Administrasi Universitas Subang

Suparmanade09@gmail.com

\begin{abstract}
Abstrak
Efektivitas Pelayanan Calon Pekerja Migran Indonesia Pada Layanan Terpadu Satu atap Dinas Tenaga Kerja dan Transmigrasi Kabupaten Subang merupakan amanat Undang-undang Republik Indonesia Nomor 18 Tahun 2017 tentang Pelindungan Pekerja Migran Indonesia. Dinas Tenaga Kerja dan Transmigrasi Kabupaten Subang memiliki tanggung jawab mengenai Pembinaan dan Pelayanan terhadap para calon pekerja migran dari mulai registrasi sampai berkas akhir pemberangkatan ke lokasi atau tujuan dia bekerja. Penelitian yang dilakukan bersifat deskriptif yaitu untuk mendapatkan data yang objektif dalam rangka mengetahui dan memahami efektifitas pelayanan Calon Pekerja Migran dengan studi Pada Dinas Tenaga Kerja dan Transmigrasi Kabupaten subang. Adapun informan adalah Kepala Bidang Penempatan Kerja, Bagian Layanan Calon Pekerja Migran dan calon pekerja migran yang tercatat di Dinas Tenaga Kerja dan Transmigrasi Kabupaten subang. Berdasarkan penelitian diketahui bahwa Efektivitas Pelayanan Calon Pekerja Migran Indonesia Pada Layanan Terpadu Satu Atap Dinas Tenaga Kerja dan Transmigrasi Kabupaten Subang dinilai belum efektif hal ini dikarenakan dimensi efektivitas menurut Sondang P Siagian (1996:60) mengenai Pengukuran efektivitas diantaranya Faktor Waktu, Faktor Kecermatan dan Faktor gaya Pemberian Layanan belum sepenuhnya dijalankan oleh para pegawai.
\end{abstract}

Kata Kunci: Efektivitas, Pelayanan 


\section{Abstract}

Effectiveness of the Services of Prospective Indonesian Migrant Workers in Integrated Services One roof of the Subang Regency Manpower and Transmigration Office is mandated by Law of the Republic of Indonesia Number 18 of 2017 concerning Protection of Indonesian Migrant Workers. The Subang Regency Manpower and Transmigration Office has the responsibility regarding the Development and Services of prospective migrant workers from the registration to the final documents of departure to the location or destination for their employment. The research is descriptive in nature, namely to obtain objective data in order to know and understand the effectiveness of the services of prospective migrant workers by studying the Subang District Manpower and Transmigration Office. The informant is the Head of Work Placement, Service Section for Prospective Migrant Workers and prospective migrant workers registered at the Subang Regency Manpower and Transmigration Office. Based on the research, it is known that the Effectiveness of Indonesian Migrant Workers Prospective Services in the One-Stop Integrated Service of the Subang Regency Manpower and Transmigration Office is considered ineffective because of the effectiveness dimension according to Sondang P Siagian (1996: 60) regarding the measurement of effectiveness including Time Factor, Accuracy Factor and Factor the style of Service Delivery has not yet been fully carried out by employees.

Keywords: Effectiveness, Service

\section{Pendahuluan}

Salah satu tugas utama negara adalah memberi pelayanan kepada masyarakat baik dalam bentuk jasa maupun fasilitas. Bahkan untuk mengukur tingkat kemajuan sebuah negara, pelayanan publik dapat digunakan sebagai salah satu indikator. Oleh karena itu, bila sebuah negara berada dalam posisi menuju pada kemajuan, hal utama yang perlu diperbaiki adalah pelayanan publik di negara tersebut. Indonesia sebagai negara yang sedang bergerak menuju negara maju juga memprioritaskan pelayanan publik sebagai salah satu aspek yang perlu ditingkatkan. Pemerintah Indonesia sangat menyadari bahwa jika masyarakat sudah mendapatkan apa yang menjadi haknya yaitu pelayanan yang baik, maka masyarakat juga akan menjalankan kewajibannya dengan penuh kesadaran. Organisasi yang efektif adalah organisasi yang mempunyai orientasi dan proyeksi dalam mengimplementasikan seluruh program kerja yang telah ditetapkan. Upaya mengevaluasi jaln suatu organisasi, dapat dilakukan melalui konsep efektivitas. Efektivitas dapat diartikan sebagai tepat sasaran yang juga lebih diarahkan pada aspek keberhasilan pencapaian tujuan. Maka efektivitas fokus pada tingkat pencapaian terhadap tujuan dari organisasi publik. Dalam kaitanya terhadap pelayanan calon pekerja migran, pemerintah berusaha menciptakan suatu system pelayanan yang optimal, salah satu dari tindakan pemerintahan tersebut adalahdengan dikeluarkanya suatu kebijakan Pelayanan Terpadu Satu Atap (LTSA). Dengan adanya LTSA ini aparatur pemberi pelayanan harus bener-bener ditata, diperbaharui dan dibenahi untuk mengubah citra aparatur yang 
sebelumnya dipandang lamban dan tidak transparan menjadi efektif sesuai dengan tujuan pelayanan publk.

Pemerintah sebagai service provider (penyedia jasa) bagi masyarakat di tuntut untuk memberikan pelayanan yang berkualitas karena salah satu fungsi pemerintahan yang kini semakin disorot masyarakat adalah pelayanan publik yang diselenggarakan oleh instansi-instansi pemerintah yang menyelenggarakan pelayanan publik. Pelayanan publik yang diberikan instansi Pemerintah (Pusat, Pemerintah Provinsi, Kabupaten, Kota dan Kecamatan) kepada masyarakat merupakan perwujudan fungsi aparatur negara sebagai abdi masyarakat disamping sebagai abdi negara. Pada era otonomi daerah, fungsi pelayanan publik menjadi salah satu fokus perhatian dalam peningkatan kinerja instansi pemerintah daerah. Terkait dengan hal tersebut maka secara otomatis berbagai jasa/fasilitas pelayanan publik harus lebih didekatkan pada masyarakat sehingga mudah dijangkau oleh masyarakat. Sesuai dengan pengertian pelayanan publik dalam Undang-Undang Nomor 25 Tahun 2009 yaitu rangkaian kegiatan dalam rangka pemenuhan kebutuhan pelayanan sesuai dengan peraturan perundang-undangan bagi setiap warga negara dan penduduk atas barang, jasa, dan/atau pelayanan administratif yang disediakan oleh penyelenggara pelayanan publik. Dalam hal ini pelayanan publik merupakan masalah serius terkait dengan penyelenggaraan pemerintahan dan akuntabilitas birokrasi dalam menjalankan kinerja dan fungsifungsi administrasi yang pada hakekanya menjadi tanggungjawab pemerintah.

Dengan diterbitkannya Peraturan Pemerintah Republik Indonesia Nomor 96 Tahun 2012 tentang Pelaksanaan Undang-Undang Nomor 25 Tahun 2009 merupakan bagian dari upaya pencapaian tujuan pelayanan publik secara efektif. Menurut Undang-undang Ketenagakerjaan Nomor 13 Tahun 2003 pasal 1 tenaga kerja adalah setiap orang yang mampu melakukan pekerjaan guna menghasilkan barang atau jasa baik untuk memenuhi kebutuhan hidup sendiri maupun untuk masyarakat. Undang-undang Ketenagakerjaan Nomor 13 Tahun 2003 pasal 4 menyatakan bahwa pembangunan ketenagakerjaan bertujuan: memberdayakan dan mendayagunakan tenaga kerja secara optimal dan manusiawi, mewujudkan pemerataan kesempatan kerja dan penyediaan tenaga kerja yang sesuai dengan kebutuhan pembangunan nasional dan daerah dan memberikan perlindungan kepada tenaga kerja dalam mewujudkan kesejahteraan tenaga kerja keluarganya. Efektivitas merupakan salah satu pencapaian yang ingin diraih oleh instansi pemerintah agar dapat memuaskan masyarakat. Efektivitas pelayanan publik mempunyai indikator nyata, kepercayaan, ketanggapan, kompetensi, kesopanan, kredibilitas, kemudahan mengakses komunikasi, dan pemahaman pelanggan. Pelayanan masyarakat yang diberikan oleh instansi pemerintah dapat dikategorikan efektif apabila masyarakat mendapatkan kemudahan pelayanan dengan prosedur yang singkat, cepat, tepat dan memuaskan.

Pembentukan Kantor Layanan Terpadu Satu Atap sebagai institusi yang khusus bertugas memberikan pelayanan langsung kepada masyarakat, pada dasarnya dapat dikatakan sebagai terobosan baru atau inovasi manajemen pemerintahan di daerah. Artinya, pembentukan organisasi ini secara empirik telah memberikan hasil berupa peningkatan produktivitas pelayanan umum minimal secara 
kuantitatif. Keberadaan Layanan Terpadu Satu Atap secara empirik telah berhasil mendongkrak efisiensi dan produktivitas pelayanan publik.

Berdasarkan hasil penjajagan awal yang dilakukan oleh peneliti mengenai Efektivitas Pelayanan Calon Pekerja Migran Indonesia Pada Layanan Terpadu Satu Atap Dinas Tenaga Kerja dan Transmigrasi Kabupaten Subang belum efektif hal tersebut dapat dilihat dari indikator permasalahan sebagai berikut: masih adanya keterlambatan dalam penyelesaian administrasi calon pekerja migran Indonesia, tidak adanya kesesuaian jumlah Calon Pekerja Migran Indonesia antara verifikasi data dari Disduk dan Rekomendasi Passpor dari Disnaker. (Bulan Januari 2019 Verifikasi data dari Disduk 263 Orang Rekomendasi Disnaker 329 Orang, bulan Februari 2019 Verifikasi data Disduk 121 Orang, rekomendasi Disnaker 324 Orang, dan bulan Maret 2019 Verifikasi data dari Disduk 198 Orang sedangkan Rekomendasi dari Disnaker 307 Orang.), masih adanya pihak ketiga yang ikut berperan dalam penyelesaian proses administrasi.

\section{Kerangka Teori}

\section{Konsep Efektivitas}

Kata efektif berasal dari bahasa inggris yaitu effective yang berarti berhasil atau sesuatu yang dilakukan berhasil dengan baik. Menurut Harbani Pasolog (2007:4), efektivitas pada dasarnya berasal dari kata "efek" dan digunakan istilah ini sebagai hubungan sebab aibat. Efektivitas dapat dipandang sebagai suatu sebab dari variable lain. Efektivitas berarti bahwa tujuan yang telah direncanakan sebelumnya dapat tercapai atau dengan kata sasaran tercapai karena adanya proses kegiatan. Pengertian efektivitas menurut ( Siagian.2001:24) efektivitas adalah pemanfaatan sumberdaya sarana dan prasarana dalam jumlah tertentu dalam jumlah sadar ditetapkan sebelumnya untuk menghasilkan sejumlah barang dan jasa kegiatan yang dijalankanya. Efektivitas menunjuk keberhasilan dari segi tercapai tidaknya sarana yang telah ditetapkan. Jika hasil kegiatan semakin mendekati sarana kegiatan, berarti makin tinggi efektivitasnya. Pandangan lain dikemukakan oleh (Sunghanda, 2003:147) bahwa efektivitas adalah pemanfaatan sumber daya, sarana dan prasarana dalam jumlah tertentu yang secara sadar ditetapkan sebelumnya untuk menghasilkan sejumlah pekerjaan tepat pada waktunya. Berdasarkan pendapat diatas penulis dapat menyimpulkan bahwa, efektivitas adalah tingkat pencapaian tujuan atau sasaran organisasional sesuai dengan yang telah ditetapkan. Melihat dari uraian mengenai efektivitas, organisasi dan efektivitas organisasi diatas, peneliti menyimpulkan bahwa efektivitas organisasi lebih dapat digunakan sebagai ukuran untuk melihat tercapai atau tidaknya suatu organisasi dalam melaksanakan kegiatan-kegiatan atau fungsi-fungsi sehingga tujuan yang telah ditetapkan dapat tercapai dengan menggunakan secara optimal alat-alat dan sumber-sumber yang ada. Efektivitas berasal dari kata efektif yang berarti tepat, tepat guna, dan berhasil. Sedangkan efektivitas itu sendiri menurut Kamus Ilmiah Populer berarti ketepatgunaan, hasil guna, menunjang tujuan. Menurut Ratminto dan Winarsih (2010:174) bahwa: “Efektivitas adalah tercapainya tujuan yang telah ditetapkan, baik itu dalam bentuk target, sasaran jangka panjang maupun misi organisasi. Akan tetapi 
pencapaian tujuan ini harus juga mengacu pada visi organisasi". Makmur (2011 : 5) menggungkapkan efektivitas berhubungan dengan tingkat kebenaran atau keberhasilan dan kesalahan. Ia berpendapat bahwa untuk menentukan tingkat efektivitas keberhasilan seseorang, kelompok, organisasi bahkan sampai kepada Negara kita harus melakukan perbandingan antara kebenaran atau ketepatan dengan kekeliruan atau yang dilakukan. Semakin rendah tingkat kekeliruan atau kesalahan yang terjadi, tentunya akan semakin mendekati ketepatan dalam pelaksanaan setiap aktivitas atau pekerjaan (tugas) yang dibebankan setiap orang. Berdasarkan pengertian tersebut efektivitas merupakan cara bagaimana organisasi dapat melaksanakan tugas, pokok dan fungsinya sehingga program atau kegiatan berjalan dengan baik dan tidak ada tegangan diantara para pelaksananya. Sehingga efektivitas bukan hanya kemampuan organisasi dalam melaksanakan tugas, tetapi juga memperhatikan komunikasi yang terjalin diantara para pelaksana kegiatan atau program agar selaras dengan tujuan yang ditetapkan. Mengingat keanekaragaman pendapat mengenai sifat dari efektivitas pada suatu organisasi, maka tidaklah mengherankan jika terdapat sekian banyak pertentangan pendapat sehubungan dengan cara-cara meningkatkan efektivitas pelayanan dalam suatu organisasi.

Ukuran-ukuran untuk efektivitas, menurut Siagian (1997:153

mengemukakan ukuran efektivitas sebagai berikut: Ukuran waktu, yaitu berapa lama seseorang yang memperoleh jasa untuk memperolehnya; Ukuran harga, dalam arti seberapa besar biaya yang harus dikeluarkan untuk memperoleh jasa yang dibutuhkannya itu; Ukuran nilai-nilai social budaya dalam arti cara penghasil jasa menyampaikan produknya kepada kliennya; Ukuran ketelitian yang menunjukan apakah jasa yang diberikan ukuran atau tidak. Berdasarkan indikator di atas dapat disimpulkan bahwa ukuran efektivitas sebagai berikut: Ukuran waktu, ukuran harga, ukuran nilai-nilai sosial budaya dan ukuran ketelitian. Menurut pendapat Cambell yang dikutip oleh Richad M. Steets dalam bukunya" efektivitas Organisasi" menyebutkan beberapa ukuran dari pada efektivitas, yaitu: Kualitas artinya kualitas yang dihasilkan oleh organisasi; Produktivitas artinya kualitas dari jasa yang dihasilkan; Kesiagaan yaitu penilaian menyeluruh sehubungan dengan kemungkinan dalam hal penyelesaian suatu tugas khusus dengan baik; Efisiensi merupakan perbandingan beberapa aspek prestasi terhadap biaya untuk menghasilkan prestasi tersebut; Penghasilan yaitu jumlah sumber daya yang masih tersisa setelah semua biaya dan jewajiban terpenuhi; dan Pertumbuhan adalah suatu perbandingan mengenai eksistensi sekarang dan masa lalunya; Stabilitas yaitu pemeliharaan struktur, fungsi dan sumber daya sepanjang waktu; Kecelakaan yaitu frekuensi dalam hal perbaikan yang berakibat pada kerugian waktu; Semangat kerja yaitu adanya perasaan terikat dalam hal pencapaian tujuan, yang melibatkan usaha tambahan, kebersamaan tujuan dan perasaan memiliki; Motivasi artinya adanya kekuatan yang muncul dari setiap individu untuk mencapai tujuan; Kepaduan yaitu fakta bahwa para anggota organisasi saling menyukai satu sama lain, artinya bekerja sama dengan baik, berkomunikasi dan mengkoosdinasikan; Keluwesan adaptasi artinya adanya suatu rangsangan baru untuk mengubah prosedur standard oprasinya, yang bertujuan untuk mencegah keterbekuan terhadap rangsangan lingkungan (dalam Steers (1985:46-48) 


\section{Konsep Pelayanan}

Sedangkan menurut Moenir (2001:26-27) memberikan pengertian pelayanan sebagai berikut: "Pelayanan umum adalah kegiatan yang dilakukan oleh seseorang atau sekelompok orang dengan landasan factor material melalui system, prosedur atau metode tertentu dalam rangka memenuhi kepentingan orang lain sesuai dengan haknya". Adapun pelayanan yang diharapkan oleh masyarakat menurut Moenir (2006:41-42) adalah sebagai berikut: Adanya kemudahan dalam pengurusan kepentingan dengan pelayanan yang cepat dalam arti tanpa hambatan yang kadangkala dibuat-buat; Memperoleh pelayanan secara wajar tanpa gerutu, sindiran atau hal-hal yang bersifat tidak wajar; Mendapatkan perlakuan yang sama dalam pelayanan terhadap kepentingan yang sama,tertib, dan tidak pandang bulu; Pelayanan yang jujur dan terus terang, artinya apabila ada hambatan karena suatu masalah yang tidak dapat dielakkan hendaknya diberitahukan, sehingga orang tidak menunggu-nunggu sesuatu yang tidak jelas.

Dari pendapat di atas dapat disimpulkan bahwa pelayanan hendaknya memuaskan keinginan masyarakat, oleh karena itu pemerintah harus memperhatikan keinginan masyarakat dari berupaya untuk meningkatkan kualitas pelayanan.

Menurut Westra dalam Enslikopedi Administrasi (dalam Ruswati (2005:18), publik adalah mengenai orang atau masyarakat. Dalam lingkup organisasi publik dibedakan menjadi dua hal sebagai berikut: Publik internal, yaitu publik didalam suatu lingkungan instansi seperti orang-orang yang merupakan anggota dari instansi tersebut dan Publik eksternal, yaitu publik diluar organisasi seperti instansi atau organisasi lain yang memiliki kepentingan dengan organisasi sebelumnya.

Pelayanan publik menurut Undang-Undang Nomor 25 Tahun 2009 adalah: "Kegiatan atau rangkaian dalam rangka pemenuhan kebutuhan pelayanan sesuai dengan peraturan perundangundangan bagi setiap warga Negara dan penduduk atas barang, jasa dan/pelayanan administratif yang disediakan oleh penyelenggara pelayanan publik". Menurut Barata (2004:11), terdapat empat unsur penting dalam proses pelayanan publik sebagaimana dijelaskan pada uraian di bawah ini: Penyedia layanan, yaitu pihak yang dapat memberikan suatu layanan tertentu kepada konsumen, baik berupa layanan dalam bentuk penyediaan dan penyerahan barang (goods) atau jasa-jasa (services); Penerima layanan, yaitu mereka yang disebut sebagai konsumen (costomer) atau customer yang menerima berbagai layanan dari penyedia layanan; Jenis layanan, yaitu layanan yang dapat diberikan oleh penyedia layanan kepada pihak yang membutuhkan layanan; Kepuasan pelanggan, dalam memberikan layanan penyedia layanan harus mengacu pada tujuan utama pelayanan, yaitu kepuasan pelanggan. Hal ini sangat penting dilakukan karena tingkat kepuasan yang diperoleh para pelanggan itu biasanya sangat berkaitan erat dengan standar kualitas barang dan atau jasa yang mereka nikmati. Menurut Ratminto dan Winarsih (2010:245) menjelaskan pendapatnya bahwa terdapat beberapa asas dalam penyelenggaraan pelayanan pemerintahan dan perizinan yang harus diperhatikan yaitu sebagai berikut:

1) Empati dengan customers. Pegawai yang melayani urusan perizinan dari instansi penyelenggara jasa perizinan harus dapat berempati dengan masyarakat pengguna jasa pelayanan. 
2) Pembatasan prosedur. Prosedur harus dirancang sependek mungkin, dengan demikian konsep one stop shop benar-benar diterapkan.

3) Kejelasan tatacara pelayanan. Tatacara pelayanan harus didesain sesederhana mungkin dan dikomunikasikan kepada masyarakat pengguna jasa pelayanan.

4) Minimalisasi persyaratan pelayanan. Persyaratan dalam mengurus pelayanan harus dibatasi sesedikit mungkin dan sebanyak yang benar-benar diperlukan.

5) Kejelasan kewenangan. Kewenangan pegawai yang melayani masyarakat pengguna jasa pelayanan harus dirumuskan sejelas mungkin dengan membuat bagan tugas dan distribusi kewenangan.

6) Transparansi biaya. Biaya pelayanan harus ditetapkan seminimal mungkin dan setransparan mungkin.

7) Kepastian jadwal dan durasi pelayanan. Jadwal dan durasi pelayanan juga harus pasti, sehingga masyarakat memiliki gambaran yang jelas dan tidak resah.

8) Minimalisasi formulir. Formulir-formulir harus dirancang secara efisien, sehingga akan dihasilkan formulir komposit (satu formulir yang dapat dipakai untuk berbagai keperluan).

9) Maksimalisasi masa berlakunya izin. Untuk menghindarkan terlalu seringnya masyarakat mengurus izin, maka masa berlakunya izin harus ditetapkan selama mungkin.

10) Kejelasan hak dan kewajiban providers dan curtomers. Hak-hak dan kewajiban-kewajiban baik bagi providers maupun bagi customers harus dirumuskan secara jelas, dan dilengkapi dengan sanksi serta ketentuan ganti rugi.

11) Efektivitas penanganan keluhan. Pelayanan yang baik sedapat mungkin harus menghindarkan terjadinya keluhan. Akan tetapi jika muncul keluhan, maka harus dirancang suatu mekanisme yang dapat memastikan bahwa keluhan akan ditangani secara efektif sehingga permasalahan yang ada dapat segera diselesaikan dengan baik.

Berdasarkan pendapat di atas maka dapat diketahui bahwa asas-asas pelayanan publik meliputi: memberikan pelayanan sebaik mungkin dan yang diberikan pelayanan merasa puas, pembatasan prosedur, kejelasan tatacara pelayanan, minimalisasi persyaratan pelayanan, kejelasan kewenangan, transparansi biaya, kepastian jadwal dan durasi pelayanan, minimalisasi formulir, maksimalisasi masa berlakunya izin, kejelasan hak dan kewajiban providers dan curtomers, dan efektivitas penanganan keluhan.

\section{Metode Penelitian}

Metode yang digunakan yaitu metode deskriptif. Menurut Sugiyono metode deskriptif (2009:21) adalah metode yang digunakan untuk mengambarkan atau menganalisis suatu hasil penelitian tetapi tidak digunakan untuk membuat kesimpulan yang lebih luas. Pendekatan kualitatif adalah pendekatan penelitian 
yang berlandaskan pada falsafat postpositivisme, digunakan untuk meneliti pada obyek yang alamiah, dimana peneliti adalah sebagai instrument kunci, pengambilan sampel sumber data yang dilakukan secara purposive dan snawbaal, teknik pengumpulan data dengan trianggulasi (gabungan), analisis data bersifat induktif/kualitatif, dan hasil penelitian lebih menekankan makna daripada generalisasi. (Sugiyono, 2009:15). Pendekatan kualitatif menekankan makna, penalaran, definisi suatu situasi tertentu (dalam kontenks tertentu), lebih banyak meneliti hal-hal yang berhubungan dengan kehidupan sehari-hari. Pendekatan kualitatif, lebih lanjut mementingkan pada proses dibandingkan dengan hasil akhir. Oleh karena itu urut-urutan kegiatan dapat berubah-ubah tergantung pada kondisi dan banyaknya gejala-gejala yang ditemukan.

\section{Hasil dan Pembahasan}

\section{Deskripsi Objek Penelitian}

Dinas Tenaga Kerja dan Transmigrasi kabupaten Subang didirikan pada tanggal 25 Januari 1965, pada saat itu pada masa pemerintahan Soeharto , dinas Tenaga Kerja dan Transmigrasi di resmikan oleh bupati pertama yaitu Bapak Sukarta yang memimpin Subang setelah dilakukan pemekaran daerah dari Kabupaten Purwakarta. Pada saat itu Dinas Tenaga Kerja dan Transmigrasi masih bertempat di kompleks kantor PEMDA Subang di Alun-alun Subang, Tetapi sekarang pindah di jalan Mayjend Sutoyo no 48. Dinas Tenaga Kerja dan Transmigrasi Kabupaten Subang terbentuk dengan dasar hukum sebagai berikut :

1. Dinas Tenaga Kerja dan Kesejahteraan Sosial Perda No. 26 Tahun 2000;

2. Dinas Tenaga Kerja dan Transmigrasi Perda No. 4 Tahun 2003;

3. Dinas Tenaga Kerja dan transmigrasi Perda No. 7 Tahun 2008.

4. Peraturan Daerah Kabupaten Subang Nomor 7 tahun 2017 Tentang Pembentukan Organisasi Perangkat Daerah Di Lingkungan Pemerintah Kabupaten Subang.

5. Peraturan Bupati Subang Nomor Tahun 2017 Tentang Struktur Organisasi Tata Kerja Dinas Tenaga Kerja Dan Transmigrasi Kabupateng Subang.

Visi Dinas adalah "Terwujudnya Tenaga Kerja dan Transmigrasi yang religius, Berilmu,Mandiri, Berbudaya, Maju dan Sejahtera serta Bergotong Royong.". Adapun misinya yaitu

a. Meningkatkan kualitas, kompetensi dan produktivitas tenaga kerja;

b. Meningkatkan pelayanan penempatan dan memperluas kesempatan kerja;

c. Meningkatkan pembinaan hubungan industrial;

d. Memfasilitasi perpindahan dan penempatan transmigrasi

e. Meningkatkan dan mengembangkan konservasi energi dan sumber daya mineral.

Berdasarkan Peraturan Daerah Kabupaten Subang Nomor 7 Tahun 2016 tentang Pembentukan dan Susunan Perangkat Daerah Kabupaten Subang dan Peraturan Bupati Subang Nomor 65 Tahun 2016 tentang Tugas Pokok dan Fungsi dan Tata Kerja Dinas Tenaga Kerja dan Transmigrasi Kabupaten Subang bahwa Dinas Tenaga Kerja dan Transmigrasi adalah unsur pendukung tugas Pemerintah Daerah 
di bidang ketenagakerjaan dan transmigrasi yang dipimpin oleh seorang Kepala Dinas yang berada di bawah dan bertanggung jawab kepada Bupati melalui Sekretaris Daerah.

\section{Pelayanan Calon Pekerja Migran}

Penempatan tenaga kerja migran adalah proses pelayanan kepada pencari kerja untuk memperoleh pekerjaan dan pemberi kerja dalam pengisian lowongan kerja sesuai bakat, minat dan kemampuan. Sedangkan menurut Undang- Undang No. 13 Tahun 2003 tentang ketenagakerjaan dalam Pasal 31 disebutkan penempatan tenaga kerja migran adalah setiap tenaga kerja mempunyai hak dan kesempatan yang sama untuk memilih, mendapatkan, atau pindah pekerjaan dan memperoleh penghasilan yang layak di dalam atau di luar negeri. Upaya penempatan tenaga kerja dilakukan pada sektor formal setiap orang berhak menduduki pekerjaan. Dengan menduduki pekerjaan yang sesuai dengan bakat, minat, dan keterampilan. Seperti operator produksi, kire worker, packing, dan marketing. Dalam Pasal 3 Peraturan Menteri Tenaga Kerja dan Transmigrasi Nomor: PER.07/MEN/IV/2008 Tentang Penempatan Tenaga Kerja, pelaksana penempatan tenaga kerja terdiri dari : Instansi pemerintah yang bertanggung jawab di bidang ketenagakerjaan; dan Lembaga swasta berbadan hukum.

Dalam hal ini upaya penempatan tenaga kerja di Dinas Tenaga Kerja dan Transmigrasi Kabupaten Subang di awali dengan menyelenggarakan : Informasi Pasar Kerja merupakan suatu keterangan mengenai karakteristik kebutuhan dan persediaan tenaga kerja yang di tempel pada papan bursa kerja maupun di upload di internet melalui Bursa Kerja Online Dinas Tenaga Kerja dan Transmigrasi Kabupaten Subang. Dalam rangka melayani Informasi Pasar Kerja melalui Bursa Kerja Online (BKO) kepada masyarakat, khususnya pengangguran dan pencari kerja dapat langsung datang ke Dinas Tenaga Kerja dan Transmigrasi Kabupaten Subang untuk langsung membuka internet yang ada di Dinas Tenaga Kerja dan Transmigrasi Kabupaten Subang secara cuma-cuma (gratis). Seperti yang diutarakan Kepala Seksi Informasi Pasar Kerja (IPK) dan Penempatan Tenaga Kerja, Informasi Pasar Kerja (IPK) di informasikan kepada masyarakat yang sedang mencari pekerjaan dan yang membutuhkan pekerjaan bahwa ada lowongan pekerjaan, seperti lowongan pekerjaan untuk Antar Kerja Antar Daerah (AKAD). Manfaat dari Bursa Kerja Online yaitu mempermudah penggunaan bagi pengangguran dalam rangka mencari pekerjaan, selain itu efisiensi waktu dan tenaga pengangguran yang ingin mencari pekerjaan sebab dalam tampilan Bursa Kerja Online telah memuat alamat dan perusahaan dengan lengkap. Informasi Pasar Kerja (IPK) sangat bermanfaat bagi pengangguran yang membutuhkan pekerjaan, sebab dengan Informasi Pasar Kerja (IPK) dapat diketahui adanya lowongan pekerjaan yang tersedia atau yang ditawarkan, baik Informasi Pasar kerja (IPK) yang di tempel di papan bursa kerja maupun yang di akses melalui Bursa Kerja Online (BKO) yang memiliki manfaat efisiensi penggunaan dan efisiensi waktu bagi pengangguran maupun yang tidak melalui Bursa Kerja Online (BKO) yang berada di papan Bursa Kerja di Dinas Tenaga Kerja dan Transmigrasi Kabupaten Subang. Sebenarnya Dinas Tenaga Kerja dan Transmigrasi Kabupaten Subang dalam melakukan Informasi Pasar kerja (IPK), dapat melalui berbagai cara. Tidak hanya melalui Bursa Kerja Online. Tuntutan 
perkembangan jaman dan teknologi yang menjadikan Bursa Kerja Online ini dianggap mampu menghemat waktu. Untuk mewujudkan pelayanan melalui peningkatan efektivitas informasi pasar kerja dan bursa kerja dalam rangka peluang terhadap pengangguran, pencari kerja dan juga pengguna tenaga kerja dan masyarakat umum. Untuk mendukung kelancaran pelaksanaan kegiatan pelayanan melalui peningkatan efektivitas Informasi Pasar Kerja dan Bursa Kerja Online (BKO), maka diharapkan bagi masyarakat untuk menyebarluaskan Informasi mengenai Bursa Kerja Online (BKO) yang berada di Dinas Tenaga Kerja dan Transmigrasi Kabupaten Subang, supaya dapat dimanfaatkan secara optimal oleh semua masyarakat, pengangguran yang membutuhkannya. Selain melalui Bursa Kerja Online (BKO), cara lain yang bisa dilakukan oleh Dinas Tenaga Kerja dan Transmigrasi dalam menyebarluaskan Informasi Pasar Kerja (IPK) kepada masyarakat khususnya pengangguran yaitu melalui radio, surat kabar atau massa media, dan pamflet-pamflet juga brosur. Dengan demikian upaya penyebaran Informasi Pasar Kerja (IPK) dapat lebih optimal dan benar-benar dapat dijangkau, diketahui oleh semua lapisan masyarakat yang membutuhkan.

\section{Efektivitas Pelayanan Calon Pekerja Migran Indonesia Pada Layanan Terpadu Satu} Atap Dinas Tenaga Kerja dan Transmigrasi Kabupaten Subang

Hasil Penelitian yang peneliti lakukan dapat disebutkan bahwa Pelayanan Calon Pekerja Migran Indonesia diperlukan karena dengan adanya konsep pelayanaan yang diberikan oleh pihak Dinas Tenaga Kerja dan Transmigrasi Kabupaten Subang melalui binaan maupun sosialisasi dan koordinasi secara rutin dengan pihak penyalur entah itu dari desa meupun calon pekerja yang langsung datang ke Layanan Satu Atap Dinas Tenaga Kerja dan Transmigrasi Kabupaten Subang , sehingga tujuan yang dicapai tepat sasaran dan sesuai dengan kebutuhan.

Untuk mengukur efektivitas Pelayanan Calon Pekerja Migran Indonesia Pada Layanan Satu Atap Dinas Tenaga Kerja dan Transmigrasi Kabupaten Subang, penulis menggunakan konsep yang memperhatikan faktor-faktor efektivitas menurut Sondang P Siagian (1996:60) terdapat beberapa cara Pengukuran efektivitas secara umum dan yang paling menonjol yaitu: Faktor Waktu, Faktor Kecermatan dan Faktor gaya Pemberian Layanan.

\section{Faktor Waktu}

Pengguna layanan akan merasa senang ketika pegawai layanan melakukan proses pelayanan dengan cepat dan tepat. Tepat dapat diartika pegawai memberikan layanan sesuai dengan keperluan pengguna layanan. Pelayanan yang tepat merupakan kesesuaian antara pelayanan yang diberikan dengan keperluan pengguna layanan sehingga keperluan yang dihadapi pengguna layanan dapat terselesaikan dengan baik dan pada akhirnya kepuasan masyarakat tercapai. Contohnya saat pengguna layanan yang melakukan registrasi maupun pendaftaran dalam mencalonkan menjadi Pekerja Migran Indonesia, seharusnya para dalam memberikan arahan maupun layanan mengenai pelaksanaan pengumpulan berkas di pandu dan dilayani dengan cepat sehingga kebutuhan pengguna layanan dapat terpenuhi. 
Berdasarkan wawancara yang dilakukan dengan Kepala Bidang Penempatan dan Perluasan Kerja Pada Layanan Terpadu Satu Atap Dinas Tenaga Kerja dan Transmigrasi Kabupaten Subang, beliau mengatakan bahwa: "Memang pada hakikatnya, Layanan Terpadu Satu Atap ini memang salah satu terobosan yang dibuat oleh Pemerintah melalui Dinas Tenaga Kerja dan Transmigrasi khusunya Kabupaten Subang untuk mewujudkan dan meingimplementasikan Undang-undang Nomor 25 tahun 2009 mengenai pelayanan Publik yang cepat dan transparan, selain itu dalam proses verifikasi data Calon Pekerja Migran sudah di fasilitasi karna Dinas Kami berkerja sama dengan Dinas Kependudukan dan Catatan Sipil untuk verifikasi data migran, selain itu berkoordinasi juga dengan Dinas Kesehatan perihal persyaratan mengenai kelayakan kesehatan melalui MCU yang dilakukan kepada para calon migran yang akan bekerja". Dari Hasil keterangan wawancara dengan Kepala Bidang Penempatan dan Perluasan Kerja Pada Layanan Satu Atap Dinas Tenaga Kerja dan Transmigrasi Kabupaten Subang, peneliti menarik kesimpulan bahwa kualitas pelayanan yang ada di Layanan Terpadu Satu Atap Dinas Tenaga Kerja dan Transmigrasi di Kabupaten Subang merupakan salah satu terobosan pemerintah pusat yang berkoordinasi dengan Pemerintah daerah dalam hal peningkatan layanan secara cepat dalam hal pelayanan calon migran Indonesia yang akan bekerja di luar negeri. Bagian Pelayanan Pada Bidang Penempatan dan Perluasan Kerja Pada Layanan Satu Atap Dinas Tenaga Kerja dan Transmigrasi Kabupaten Subang menyatakan: “Dalam memberikan Pelayanan terhadap calon pekerja migran memang tidak ada jaminan waktu yang mengatur mengenai hal itu dikarenakan setiap kami melayani para calon Imigran ada saja berkas yang kurang lengkap dari Calon pekerja migran, seperti Syarat Keterangan Sudah Menikah (Bagi yang sudah menikah) dengan melampirkan Surat Persetujuan Suami, dan Juga Surat Persetujuan Orang tua/wali bagi Calon pekerja migran yang belum menikah, kalu persyaratan itu sudah lengkap waktu penyelesaian berkas hingga penentuan penempatan kerja pasti cepat tidak lebih dari 3 hari itupun sudah veridikasi data dari Diduk dan persyaratan MCU para calon Imigran ". Dari Hasil keterangan wawancara dengan Bagian Pelayanan Pada Bidang Penempatan dan Perluasan Kerja Pada Layanan Satu Atap Dinas Tenaga Kerja dan Transmigrasi Kabupaten Subang, peneliti menarik kesimpulan bahwa ada keterlambatan yang dinilai menghambat dalam proses pelayanan yang ada Pada Layanan Satu Atap Dinas Tenaga Kerja dan Transmigrasi Kabupaten Subang yaitu masalah kelengkapan berkas atau persyaratan para calon pekerja migran yang seringkali ditemukan banyak dokumen yang kurang lengkap yang menghambat waktu pelayanan. Peneliti mencoba mewawancarai Informan Calon Pekerja migran yang sedang mengurus berkas di Layanan Terpadu Satu Atap Dinas Tenaga Kerja dan Transmigrasi Kabupaten Subang, beliau mengatakan: "Dalam memberikan Pelayanan terhadap Calon pekerja migran para petugas bidang pelayanan dinilai sudah baik kalau dilihat dari waktu pelaksanaan, karna dalam registrasi calon pekerja migran perlu verifikasi E-KTP dulu dari pihak Disdukcapil, namun kadangkala yang membuat lama itu ialah pada saat Medical Check Up kesehatan, karna hasilnya tidak bisa langsung dilihat sehingga kami harus menunggu untuk tahap pengumpulan data selanjutnya". Dari Hasil keterangan wawancara dengan Calon Pekerja migran, peneliti menarik kesimpulan bahwa jika dinilai dari proses alur pengumpulan berkas oleh para calon 
pekerja migran banyak kendala yang dinilai menghambat proses Pengumpulan berkas, misalnya para calon pekerja migran harusmenunggu verifikasi data dari Disdukcapil Kabupaten subang untuk tahap selanjutnya. Dari beberapa pernyataan informan diatas mengenai Dimensi Faktor Waktu dalam menunjang efektivitas pelayanan di Layanan Terpadu Satu Atap Dinas Tenaga Kerja dan Transmigrasi Kabupaten Subang jika dikaitkan dengan teori efektivitas menurut Sondang P Siagian (1996:60) dinilai belum efektif dilihat dari tidak adanya jaminan waktu yang diberikan oleh bagian pelayanan dan masih banyak kendala yang menghambat proses pelayanan mengenai penyelesaian .berkas para calon pekerja migran Indonesia yang ada di Kabupaten Subang.

\section{Faktor Kecermatan}

Kecermatan atau ketelitian pegawai dalam melayani pengguna layanan sangat penting bagi proses pelayanan. Jika pegawai tidak cermat dalam melayani masyarakat maka akan terjadi kesalahan dan menimbulkan pekerjaan baru. Sebagai contoh ketika pegawai salah ketik dalam penulisan nama pada form berkas calon pekerja migran, maka pengguna layanan harus mengurus kembali nama yang salah tersebut. Dari ketidakcermatan tersebut akan menimbulkan pekerjaan baru yang seharusnya tidak perlu dilakukan oleh pegawai, serta akan menimbulkan penilaian yang kurang baik oleh pengguna layanan terhadap kualitas pelayanan yang diberikan. Maka dari itu pegawai harus cermat dalam mengerjakan tanggung jawab tugas khususnya yang berkaitan dengan pelayanan agar tercipta pelayanan yang baik dan masyarakat akan menilai baik. Peneliti mencoba mewawancarai Kepala Bidang Penempatan dan Perluasan Kerja Pada Layanan Terpadu Satu Atap Dinas Tenaga Kerja dan Transmigrasi Kabupaten Subang, beliau mengatakan: "Kalau berbicara masalah kecermatan berkaitan dengan ketelitian pegawai dalam hal pemberian layanan input data maupun koordinasi antar lembaga yang kami lakukan dengan Disdukcapil sebagai lembaga yang berkoordinasi mengenai pencocokan data calon pekerja migran, memang kalau masalah data masih sering ditemukan data yang tidak sinkron antara jumlah pelamar pekerja migran yang ada di Disnaker dan Disdukcapil, memeng ini merupakan problema masih kami perbaiki secara bertahap". Dari Hasil keterangan wawancara dengan Kepala Bidang Penempatan dan Perluasan Kerja Pada Layanan Satu Atap Dinas Tenaga Kerja dan Transmigrasi Kabupaten Subang, peneliti menarik kesimpulan bahwa kecermatan atau ketelitan pegawai dalam memberikan layanan belum cukup efektif dinilai masih banyak data calon imigran yang harus diperbaiki dan dan di data ulang sehingga data yang ada di Disnaker dan Disdukcapil bisa sinkron dan sesuai dengan E-KTP para calon pekerja migran yang ada di Kabupaten Subang. Dari Hasil keterangan wawancara dengan Calon Pekerja migran, peneliti menarik kesimpulan bahwa jika dinilai dari sikap pegawai, masih banyak pegawai yang menampakan wajah jutek terhadap para penerima layanan yang mengakibatkan para penerima layanan dinilai merasa canggung dan sulit berkomunikasi dan bertanya mengenai proses pengumpulan berkas maupun dokumen para calon pekerja migran di Kabupaten Subang. Dari beberapa pernyataan informan diatas mengenai Dimensi Faktor Kecermatan dalam menunjang efektivitas pelayanan di Layanan Terpadu Satu Atap Dinas Tenaga Kerja dan Transmigrasi Kabupaten Subang jika dikaitkan dengan teori efektivitas menurut Sondang P Siagian 
(1996:60) dinilai belum efektif dilihat dari kurang cermatnya para pegawai dalam proses input data dan verifikasi data selalu banyak yang tidak sinkron dengan data Disdukcapil, selanjutnya masalah kecermatan pegawai dalam memberikan layanan dinilai belum efektif dikarenakan ada keluhan dari informan calon pekerja migran yang menilai petugas layanan kurang ramah dalam memberikan layanan terhadap penerima layanan.

\section{Faktor Gaya Pemberian Layanan}

Gaya Pemberian Layanan yaitu mencakup pengetahuan, kemampuan, kesopanan dan sifat dapat dipercaya yang dimiliki pegawai, bebas dari bahaya, resiko, dan keraguraguan. Gaya adalah karakter mengenai upaya perlindungan yang disajikan untuk masyarakat bagi warganya tehadap resiko yang apabila resiko itu terjadi akan dapat mengakibatkan gangguan dalam struktur kehidupan yang normal. Untuk mengukur gaya pemberian layanan dalam upaya mengetahui

kualitas pelayanan Layanan Satu Atap Dinas Tenaga Kerja dan Transmigrasi Kabupaten Subang dapat diukur melalui indikator sebagai berikut:

\section{Kenyamanan dalam memberikan layanan}

Kenyamanan tempat dalam proses pelayanan sangat penting bagi pengguna layanan. Selain itu tempat pelayanan juga sangat mempengaruhi kualitas pelayanan Layanan Satu Atap Dinas Tenaga Kerja dan Transmigrasi Kabupaten Subang sebagai penyedia layanan publik harus memberikan kenyamanan tempat bagi pengguna layanan yang datang, dari menyediakan tempat yang cukup agar pengguna layanan tidak merasakan sempit di dalam ruangan, kemudian menyediakan tempat duduk yang disesuaikan dengan ruangan yang ada. Berkaitan dengan kenyamanan tempat pelayanan, Peneliti mencoba mewawancarai informan Calon Pekerja Imigran yang ada di Layanan Terpadu Satu Atap Dinas Tenaga Kerja dan Transmigrasi Kabupaten Subang, beliau menyatakan: “Tempat pelayanan ini belum nyaman karena banyak kertas yang berantakan di atas meja dan belum tertata dengan rapi, selain itu pelayananya dinilai kurang ramah serta kurang senyum pegawainya." Dari Hasil keterangan wawancara dengan Calon Pekerja Imigran, peneliti menarik kesimpulan bahwa jika dinilai dari kenyamanan tempat pelayanan dinilai masih kurang efektif, dilihat dari berkasberkas yang kurang rapih di atas meja dan selanjutnya gaya pemberi layanan dinilai kurang memberikan pelayanan yang perima dengan memberikan konsep 35 (Senyup, Sapa dan Salam).

Selanjutnya Kepala Bidang Penempata dan Perluasan Kerja Pada Layanan Terpadu Satu Atap Dinas Tenaga Kerja dan Transmigrasi Kabupaten Subang menjelaskan bahwa: "Kenyamanan tempat pelayanan sangat mempengaruhi kualitas dari pelayanan gaya pemberian layanan karena jika masyarakat harus menunggu dengan suasana ruangan yang tidak nyaman maka masyarakat pun akan menjadi tidak nyaman. Jika pengguna layanan harus mengantri dengan suasana nyaman dan bersih maka masyarakat akan bersedia untuk bersabar. Tetapi sebaliknya jika proses pelayanan lama dan tempat pelayanan kurang nyaman dan tidak bersih maka masyarakat tidak akan merasa nyaman. Oleh karena itu, masih terdapat keluhan dari masyarakat sebagai pengguna layanan terkait kenyamanan 
tempat pelayanan. Masyarakat menyampaikan bahwa jika sudah siang hari ruangan menjadi panas ". Kenyamanan tempat pelayanan mempengaruhi proses pelayanan. Penyedia layanan harus lebih memperhatikan kenyamanan untuk pengguna layanan. Apabila tempat yang disediakan oleh pengguna layanan baik, maka pengguna layanan akan merasa nyaman. Namun sebaliknya jika tempat yang disediakan tidak layak maka pengguna layanan tidak akan merasa nyaman.

\section{Petugas memberikan jaminan biaya dalam pelayanan}

Dalam mengurus keperluan calon pekerja migran, biaya yang dikeluarkan untuk mengurusnya sebenarnya gratis alias tidak dipungut biaya. Namun slalu adaiaya yang mesti dikeluarkan dengan dalil biaya administrasi dan lain sebagainyagar pelayanan bersifat cepat dan waktu yang di tentukan sesuai. Berikut hasil wawancara dengan informan calon pekerja migran yang sedang mengurus berkas di Kantor Layanan Terpadu Satu Atap Dinas Tenaga Kerja dan Transmigrasi Kabupaten Subang: “Memang untuk bisa menjadi calon pekerja migran, awalnya saya bingung harus bagaimana, katanya harus ada uang untuk biaya awal sebesar 3 juta Rupiah,namun saya kurang memahami itu untuk apa. Saya tidak permaslahkan itu sebenarnya, yang saya pikirkan yang penting saya lolos tahap verifikasi dan saya bisa bekerja untuk kedepanya". Dapat ditarik kesimpulan bahwa masalah jaminan biaya yang ada di Kantor Layanan Terpadu Satu Atap Dinas Tenaga Kerja dan Transmigrasi Kabupaten Subang pada dasarnya tidak dikenakan biaya, namun kenyataan dilapangan banyak praktek-praktek pemungutan biaya yang dilakukan oleh beberapa petugas dengan dalil agar proses dapat cepat selesai. Bagian Pelayanan Pada Bidang Penempatan dan Perluasan Kerja Pada Layanan Satu Atap Dinas Tenaga Kerja dan Transmigrasi Kabupaten Subang Perindustrian juga menambahkan: "Memang masih ada oknum-oknum calo yang suka menawarakan kepada para calon pekerja migran yang domisilinya jauh dari kota dengan di iming-imingi diterima kerja dan mendapatkan gajih besar, namun pada kenyataanya semua calon pekerja migran harus melewati tahap verifikasi data maupun lulus test MCU baru bisa dinyatakan bekerja sesuai penempatan kerjanya " Dari beberapa pernyataan informan diatas mengenai Dimensi Faktor Gaya Pemberian Layanan dalam menunjang efektivitas pelayanan di Layanan Terpadu Satu Atap Dinas Tenaga Kerja dan Transmigrasi Kabupaten Subang jika dikaitkan dengan teori efektivitas menurut Sondang Siagian (1996:60) dinilai belum efektif dilihat dari kenyamanan tempat pelayanan dan masih banyak ikut campur orang ke-tiga dalam proses pelayanan calon pekerja migran sehingga merubah citra pelayanan Layanan Satu Atap Dinas Tenaga Kerja dan Transmigrasi Kabupaten Subang yang awalnya baik menjadi kurang baik.

\section{Kesimpulan}

Berdasarkan pemaparan bab sebelumnya, dapat di tarik kesimpulan sebagai berikut :Efektivitas Pelayanan Calon Pekerja Migran Indonesia Pada Layanan Terpadu Satu Atap Pada Dinas Tenaga Kerja dan Transmigrasi Kabupaten Subang dinilai belum efektif, berikut pemaparannya : 
Faktor Waktu, Bidang Penempatan dan Perluasan calon pekerja migran Pada Layanan Terpadu Satu Atap Pada Dinas Tenaga Kerja dan Transmigrasi dalam dimensi Faktor Waktu masih dinilai belum efektif dilihat dari tidak adanya jaminan waktu yang diberikan oleh bagian pelayanan dan masih banyak kendala yang menghambat proses pelayanan mengenai penyelesaian berkas para calon pekerja migran Indonesia.

Faktor Kecermatan, Kemudian dalam dimensi Faktor Kecermatan para pegawai khusunya Bidang Penempatan dan Perluasan calon pekerja migran Pada Layanan Terpadu Satu Atap Pada Dinas Tenaga Kerja dan Transmigrasi dinilai belum efektif dilihat dari kurang cermatnya para pegawai dalam proses input data dan verifikasi data selalu banyak yang tidak sinkron dengan data Disdukcapil,

Faktor Gaya Pemberi Layanan, Dan yang terakhir pada dimensi Faktor Gaya Pemberi Layanan dinilai belum efektif dikarenakan tempat pelayanan dinilai belum memberikan kenyamanan, selanjunya pemberi layanan kurang ramah dan yang terakhir masih ada oknum atau orang ke tiga yang ikut campur dalam proses penyelesaian administrasi.

\section{Referensi}

Adya Atep Barata. (2004). Dasar-dasar Pelayanan Prima, Cetakan 2. Jakarta : PT Elex Media Komputindo.

Handayaningrat, Soewarno, Drs. 2006. Pengantar Studi Ilmu Administrasi dan Manajemen. Jakarta : Gunung Agung

Hayat, 2017. Manajemen Pelayanan Publik, . Jakarta : Raja Grafindo Persada

Hidayat. 2006. Teori Efektivitas Dalam Kinerja Karyawan. Yogyakarta : Gajah Mada University Press.

Kepmenpan no.63 tahun 2003 tentang Pedoman Umum Penyelenggaraan Pelayanan Publik

Keputusan Menteri Pendayagunaan Aparatur Negara No.63/KEP/M.PAN/7/2003 Kurniawan, Agung. 2005. Transformasi Pelayanan publik. Yogyakarta pembaruan. Moenir,A.S.Drs. 2006, Manajemen Pelayanan Umum di Indonesia Jakarta, PT. Bumi Aksara

Moenir,H.A.S, 2001. Manajemen Pelayanan Umum Di Indonesia. Jakarta: Bumi Aksara

Moleong Lexy J.M.A.2007. Metodelogi Penelitian Kualitatif. PT Remaja Rosdakarya. Bandung

P.Siagian Sondang 2002, Administrasi Pembanguna. Jakarta: PT. Bumi Aksara. Pasalog, Harbani.2007. Teori Administrasi Publik. Bandung. Alfabeta

Ratminto dan Atik Septi Winarsih, 2005 (cetakan 1), Manajemen Pelayanan: Pengembangan Model Konseptual, Penerapan Citizens charter dan Standar Pelayanan Minimal. Yogyakarta: Pustaka Pelajar. 


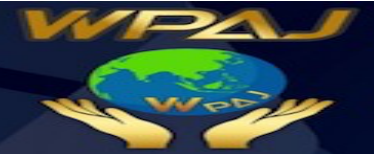

Volume 2 Issue 2, Desember 2020

http://ejournal.unsub.ac.id/index.php/publik

Ratminto dan Atik Septi Winarsih.2010. Manajemen Pelayanan. Yogyakarta: Pustaka Pelajar

Sedarmayanti, M.Pd, APU. 2009, Sumber Daya Manusia dan Produktivitas Kerja. Bandung: Penerbit Mandar Maju.

Siagian, Sondang P,2001 Manajemen Sumber Daya Manusia, Jakarta: PT. Bumi Aksara

Sinambela,L,P,dkk.2006, Reformasi Pelayanan Publik: Teori, Kebijakan, dan Implementasi. Jakarta. Bumi Aksara

Sondang P.Siagian 1996, Organisasi dan perilaku Administrasi. Jakarta: Bumi, Aksara.

Steers, Richard M. 2005. Efektivitas Organisasi. Terjemahan Magdalena Jamin. Erlangga. Jakarta. Tentang Pedoman Umum Penyelenggaraan Pelayanan Publik.

Undang-undng no.25 tahun 2009 tentang Pelayanan Publik.

Undang-undang Repulik Indonesia Nomor 13 Tahun 2003 Tentang Ketenagakerjaan. 